\title{
Çalışanların örgütsel güven algılarının işten ayrılma niyeti ve örgütsel özdeşleşme üzerine etkisi: Trabzon kereste ve mobilya işletmeleri örneği
}

\author{
Nadir Ersen ${ }^{1 *(D)}$, Öner Karayiğit² ${ }^{2}$, Bahadır Çağrı Bayram³ ${ }^{3}$, İlker Akyüz ${ }^{4}$ (D)
}

$\ddot{\mathbf{O} z}$

$\mathrm{Bu}$ çalışmada, örgütsel güven alt boyutlarının işten ayrılma niyeti ve örgütsel özdeşleşme üzerine etkisinin belirlenmesi amaçlanmıştır. Aynı zamanda, kereste ve mobilya alanlarında faaliyet gösteren işletmelerde çalışan kişilerin örgütsel güven algıları ile işten ayrılma niyeti ve örgütsel özdeşleşme düzeyleri arasındaki ilişki tespit edilmeye çalışılmıştır. Çalışma evrenini Trabzon'daki ağaç ve ağaç ürünleri ve mobilya işletmelerinde çalışan kişiler (1507 kişi) oluşturmaktadır. Çalışma kapsamında 315 çalışana yüz-yüze yöntem ile anket uygulanmıştır ve 305 anket analizde kullanılmıştır. Çalışma sonucunda, örgütsel özdeşleşmenin en yüksek puan ortalamasına sahip olduğu bulunmuşken, işten ayrılma niyetinin en düşük puan ortalamasına sahip olduğu bulunmuştur. Çalışanlar en fazla iş arkadaşlarına ve en az örgüte güvendiklerini söylemiştir. Örgütsel güven boyutu ve alt boyutları ile işten ayrılma niyeti arasında anlamlı ve negatif ve örgütsel güven boyutu ve alt boyutları ile örgütsel özdeşleşme arasında anlamlı ve pozitif bir ilişki bulunmuştur. Son olarak, yöneticiye güven boyutunun işten ayrılma niyetini negatif yönde etkilediği belirlenirken, iş arkadaşlarına güven ve örgüte güven boyutlarının ise örgütsel özdeşleşmeyi pozitif yönde etkilediği belirlenmiş̧ir.

Anahtar kelimeler: Örgütsel güven, İşten ayrılma, Özdeşleşme, Kereste-mobilya sektörü

\section{The effect of organizational trust perceptions on turnover intention and organizational identification of employees: the case of Trabzon timber and furniture enterprises}

\begin{abstract}
In this study, it was aimed to determine the effect of organizational trust sub-dimensions on turnover intention and organizational identification. At the same time, the relationship between organizational trust perceptions and turnover intention and organizational identification levels of people working in enterprises operating in the fields of timber and furniture was tried to be determined. The population of the study consists of people (1507 people) working in wood and wood products and furniture enterprises in Trabzon. Within the scope of the study, a face-to-face survey was applied to 315 employees, and 305 surveys were used in the analysis. As a result of the study, it was found that organizational identification had the highest mean score, while turnover intention had the lowest mean score. Employees stated that they trust their colleagues the most and the organization the least. A significant and negative relationship was found between the organizational trust dimension and its subdimensions and the turnover intention, and a significant and positive relationship between the organizational trust dimension and its sub-dimensions and organizational identification. Finally, it was determined that the dimension of trust in the manager negatively affected the intention to leave, while the dimensions of trust in colleagues and trust in the organization positively affected organizational identification.
\end{abstract}

Keywords: Organizational trust, Turnover, Identification, Furniture and timber industry 


\section{Giriş}

Günümüzde artan rekabet, müşteri ve kalite beklentilerinin yüksek olması nedeniyle örgütler çalışanlarından sorumluluk kabulü ve inovasyona dahil olmalarını beklemektedir. Böyle bir çağda, kuruluşların hayatta kalabilmeleri için çevresel zorluklara iyi tepki veren, bilgiyi paylaşmaktan korkmayan ve kendi ve arkadaşlarının inançları için girişimde bulunan insanlara ihtiyacı vardır. Diğer bir ifadeyle, kuruluşlar örgütleri rekabet ortamında hayatlarını sürdürdüğü müddetçe kendilerinin de hayatlarını sürdüreceği hissiyatını taşıyan yani örgütle özdeşleşen kişilere ihtiyaç duymaktadır. Örgüt içerisinde örgütsel özdeşleşmenin sağlanabilmesi için kişilerin iş arkadaşlarına, yöneticilerine ve örgütüne güvenmesi gerekmektedir.

Güvenin oluşmadığı ve çalışanların kendini örgütün bir parçası olarak görmediği işletmelerde işten ayrılmalar artmakta, bunun sonucu olarak da örgütlerde doğrudan ve dolaylı maliyetler oluşmaktadır. Örgüt yöneticileri için en büyük sorunların başında kişinin kendi isteğiyle ayrılması gelmektedir. Çünkü işten ayrılma niyeti çalışanda performans düşüklüğüne ve işin yavaşlamasına neden olmaktadır. Niyetin eyleme dönüşmesi ile kalifiye bir çalışanın işten ayrılması neticesinde üretim azalmakta, kalite düşmekte ve masraflar artmaktadır. Üretim aşamasında oluşacak masrafların dışında, ayrılan personelin gelişimi için harcanan zaman ve para da ayrılan personelle birlikte yok olup gitmektedir. Tekrar aynı pozisyona personel alınana kadar geçen zamanda oluşacak üretimsel sorunlar ve kayıplar, yeni personelin eğitimi için harcanan zaman ve para ise şirketler için oldukça önemli bir kalemi temsil etmektedir.

\section{1 Örgütsel Güven Kavramı}

Örgütsel güven genel olarak, "bir başkasının niyetleri veya davranışlarına ilişkin olumlu beklentilere dayalı olarak savunmasızlığ kabul etme niyetini içeren psikolojik bir durum" olarak tanımlanmaktadır (Rousseau ve ark., 1998). Örgütsel güven farklı hedeflere (iş arkadaşları, yöneticiler, kuruluşlar) ve analiz birimlerine (bireysel düzeyde veya grup düzeyinde güven) atıfta bulunarak ortaya çıkabilir. Bu çalışmada, üç önemli nedenden dolayı çalışanların örgütlerine ne ölçüde güvendiğini gösteren örgütsel güvene odaklanılmıştır. Birincisi, örgütsel güven, işten ayrılma niyetleri, örgütsel bağl1lık, örgütsel özdeşleşme, örgütsel vatandaşlık davranışları ve iş tatmini gibi örgütsel tutumların öncülü olarak hayati bir rol oynamaktadır. İkincisi, güven özellikle kriz ve belirsizlik zamanlarında önemlidir. Üçüncüsü, örgütsel güven, yöneticiler de dahil olmak üzere liderlerin eylemleri, davranışları ve iletişiminden oldukça etkilenmektedir ( Guzzo ve ark., 2021).

Güvenin hem örgütü hem de bireye birçok olumlu ve olumsuz yönleri bulunmaktadır. Bir örgütün güven düzeyi ne kadar yüksek olursa, o örgütte çalışanlar örgüte gelmeye daha istekli olacaktır. Çalışanlar işleri severek yaptıklarından dolayı performanslarında artış olacaktır ve sonuç olarak örgütün verimliliği de artacaktır. Örgütteki personel devir hızı düşecektir. Örgütte meydana gelen çatışmalar azalacaktır. Bir örgütte güven olmadığında ya da az olduğunda çalışanlar yaptıkları işlerinden dolayı yöneticiler tarafından fark edilmediklerini hissettikleri ve övülmedikleri için daha fazla çaba harcamaya gerek olmadığını düşünebilir. $\mathrm{Bu}$ düşünceyle beraber çalışanların performanslarında düşüşler yaşanabilir ve bu durum ürün kalitesini de etkileyebilir. Çalışanlar örgütte mutlu olmadığ işe gitmek istemeyebilir. Örgütteki personel devir hızında artışlar olabilir (Halis ve ark., 2007). 


\section{2 İşten Ayrılma Niyeti Kavramı}

İşten ayrılma, çoğu zaman istenmese de her sektörde işletmelerin yaşam seyri boyunca tecrübe ettiği faydadan çok zararları üzerinde durulan çok önemli ve dikkat edilmesi gereken bir durumdur. İşten ayrılmalar bazen işletmelerin kontrolünde bazen de kontrolü dışında gerçekleşmektedir. İşletmenin etkinliğini ve verimliliğini etkilediği için işten ayrılma süreci ve işten ayrılmaya neden olan faktörler dikkatlice incelenmelidir. Bu noktada işten ayrılma davranışının çok önemli bir işareti olan işten ayrılma niyeti kavramı göze çarpmaktadır. İşten ayrılma niyeti basit bir ifadeyle bir çalışanın, çalıştığı örgütten ayrılmayı düşünmesi veya planlaması şeklinde ifade edilmektedir. İşten ayrılma fikri veya düşüncesi örgütten fiilen ayrılmadan önceki adım olarak da değerlendirilmektedir (Yücel ve Demirel, 2013).

Çalışanların örgütten ayrılma niyetlerini belirleyen birçok faktör bulunmakta olup, bu faktörler kişisel (yaş, cinsiyet, görev süresi, tükenmişlik, vb.) örgütsel (örgütsel bağl1lı, örgütsel adalet algısı, çalışma performansı, örgütsel özdeşleşme, vb.) ve dışsal faktörler (işsizlik oranı, ülkenin ekonomik durumu, sendikaların varlığı, vb.) olarak nitelendirilmektedir (Cotton ve Tutle, 1986; Yenihan ve ark., 2014; Ismaeel, 2020).

İşten ayrılma örgütlere olumsuz sonuçlar doğurmaktadır. İşten ayrılan personel yerine yeni personelin elde edilmesi için verilen ilan bedeli, yapılan mülakat ve testler veya danışmanlara verilen danışmanlık ücretleri, yeni işe girecek olan personel için harcanan eğitim giderleri, yeni işe giren personelin iş uyum sürecinde meydana gelme ihtimali olan hasar ve kaza maliyetleri, personelin işten ayrılmasında dolayı kıdem tazminatı gibi ayırma maliyetleri, yeni işe başlayan personelin tam kapasite ile çalışıncaya kadar geçen süre zarfinda diğer personele ödenen fazla mesai ücretleri ve yeni personelin işe girmesi ile eski personelin işten istifası arasında geçen zamanda oluşabilecek üretim ve hizmet kayıplarının maliyetleri işletmeler için ekonomik kayba yol açmaktadır (Hinkin ve.Tracey, 2000; Sanderson, 2003; Gemlik, 2018). Ayrıca, bir işletmede işten ayrılan personel sayısının yüksek düzeyde olması işletmede çalışan diğer personeller üzerinde moral bozukluğu, iş güvensizliği ve buna bağlı olarak personelde motivasyon eksikliği oluşturabilir (Gemlik, 2018).

\section{3 Örgütsel Özdeşleşme Kavramı}

Günümüzde şirketler, çalışanlarından işyerini sevmek, işe sadık olmak ve işine bağlı olmak gibi bazı duyguların ötesine geçmelerini beklemekte ve şirketler, çalışanlarından işletmeyi bireysel kimlikleriyle özdeşleştirecek şekilde benimsemelerini istemektedir. Örgüt üyeliğini çalışanların kişiliklerinin önemli bir parçası haline getirmek ve çalışanların kendilerini tanıtırken örgüt üyeliğinden gurur duymalarını sağlamak, işletmelerin stratejik avantajlar elde etmeleri için rekabet ortamında oldukça önemlidir. Bu nedenle örgütsel özdeşleşme konusu günümüz işletmeleri açısından anlaşılması gereken bir kavramdır (İşçan, 2006; Taştan, 2020).

Literatürde örgütsel özdeşleşme ile ilgili birçok tanım bulunmaktadır. Mael ve Ashforth (1992), bireyin örgüte olan psikolojik yakınlığı ile birlikte örgütün başarı ve başarısızlıklarını kendisine ait olarak algılaması durumu olarak tanımlamaktadır. Scott ve Lane (2000) örgütsel özdeşleşmeyi, bireyin örgütü tanımlarken kendisini örgütün ayrılmaz bir parçası olarak görmesi olarak ifade etmiştir. Bireylerin içinde çalıştıkları örgütün değer ve amaçlarının bir parçası olma ya da bunlarla özdeşleşme derecesi hem bireyler hem de örgütler için önemlidir. Bireyler için örgütsel özdeşleşme, kendilerini örgütle birlikte sosyal bir varlık olarak tanımladıkları bir kimlik duygusu ve kendini tanımlama sağlamaktadır (Karanika-Murray ve ark., 2015). Bireyin örgütüyle özdeşleşmesi ne kadar güçlü olursa, bireyin örgütün amaç ve beklentilerine göre hareket etmesi ve örgütte kalmaya istekli olması o kadar yüksek ve 
organizasyonun hedeflerine ulaşması o kadar daha hızlı olacaktır (Karanika-Murray ve ark., 2015; Hamzagic, 2018). Aynı zamanda örgütsel özdeşleşme çalışan davranışları, tutumları ve bilişleri üzerinde güçlü bir etkiye sahiptir. Akademisyenler, çalışanların bağlılığını ve performansını artırmasında örgütsel özdeşleşmeyi "sihirli bir kurşun" olarak benimsemiştir (Blader ve ark., 2017). Örgütsel özdeşleşmenin gücü, örgütsel imaj ve prestij ile de ilişkilidir. Çalışanların tutumları, örgütün performansının yönlerinden etkilenmektedir (Hamzagic, 2018). Örgütün iyiliği bireyin çıkarına olduğu için, örgüt veya çalışma grubuyla özdeşleşme eksikliği, hedeflerde ve motivasyonda tutarsızlıklara yol açarak motivasyon ve iş tatmininin azalmasına yol açabilir. Son olarak örgütsel özdeşleşme, işten, bağlılık, işbirliği ve değişime direnç gibi bir dizi iş davranışını anlamaya yardımcı olabilir (Karanika-Murray ve ark., 2015). Yüksek örgütsel özdeşleşmeye sahip olmak fiili olarak örgütün performansının daha iyi olacağı anlamına da gelmemektedir. Riketta'nın (2005) çalışması, özdeşleşme ile rol içi performans ve ekstra rol davranışı arasındaki zayıf ile orta düzeydeki ilişkiyi göstermektedir (Hamzagic, 2018). Bu çalışmada örgütsel güven, işten ayrılma niyeti ve örgütsel özdeşleşme kavramlarına yer verilmiş, örgütsel güven alt boyutlarının işten ayrılma niyeti ve örgütsel özdeşleşme boyutlarına etkisi belirlenmeye çalışılmıştır.

\section{Materyal ve Metot}

\subsection{Materyal}

Çalışmanın materyalini Trabzon'da faaliyet gösteren kereste ve mobilya işletmelerinde çalışan kişiler oluşturmaktadır. Çalışma evrenini Trabzon'da faaliyet gösteren ve TOBB sanayi veri tabanına kayıtlı 32 ağaç, ağaç ürünleri ve mantar ürünleri işletmesinde çalışan 504 çalışan ve 23 mobilya işletmesinde çalışan 1003 çalışan olmak üzere toplam 1507 çalışan oluşturmaktadır (URL1, 2021). Çalışma kapsamında hazırlanan anket formu 315 çalışana uygulanmıştır ve anketlerden 305 tanesi değerlendirmeye alınmıştır. Ayrıca, bu anket formu çalışanlara yüz yüze şeklinde uygulanmıştır. Toplam çalışan sayısına (N) göre;

$$
n=\frac{Z^{2} N P Q}{N D^{2}+Z^{2} P Q}
$$

Formülünden yararlanılarak örnek büyüklüğü belirlenmiştir (Dorman ve ark., 1990). Formülde kullanılan simgeler ise şunlardır;

n: Örnek büyüklüğü, $Z$ : Güven katsayısı (\%90'lık güven katsayısı 1.64 olarak alınmıştır), $P$ : Ölçmek istediğimiz özelliğin ana kütlede bulunma ihtimali (çalışmamızın çok amaçlı olmasından dolayı bu oran \%50 alınmıştır), $Q: 1-P, D:$ Kabul edilen örnekleme hatası (\%5 alınmıştır). Böylece örnek büyüklüğ̈̈;

$$
n=\frac{1,64^{2} * 1507 * 0.5 * 0.5}{1507 * 0.05^{2}+1.64^{2} * 0.5 * 0.5}=228
$$

olarak bulunmuştur.

\subsection{Metot}

Çalışmada yöntem olarak yüz-yüze anket yönteminden yararlanılmıştır. Hazırlanan anket formu dört bölümden oluşmaktadır. Birinci bölümde katılımcıların demografik özellikleri ile ilgili sorular yer alırken ikinci bölümde katılımcıların örgütsel güven algıları ile ilgili sorular yer almaktadır. Bunun için örgütsel güven ölçeği kullanılmıştır. Üçüncü ve dördüncü bölümlerde ise sırasıyla katılımcıların işten ayrılma niyetleri ve örgütsel özdeşleşme algıları ile ilgili sorular yer almaktadır. İşten ayrılma niyeti için işten ayrılma ölçeği ve örgütsel özdeşleşme için örgütsel özdeşleşme ölçeği kullanılmıştır. Çalışmada kullanılan 
ölçeklerin yapısal geçerliliğini belirlemek için ise faktör analizi uygulanmıştır. Faktör analizi uygulanırken faktör yüklerinin 0.30 'tan büyük olmasına ve bitişik durumdaki maddeler arasındaki faktör yükü farkının 0.10 veya bu değerden büyük olmasına ve Varimax döndürme yönteminin kullanılmasına dikkat edilmiştir (Karaman, 2015).

Örgütsel güven ölçeği olarak Omarov (2009) tarafından geliştirilen ölçek kullanılmıştır. Ölçek 22 maddeden ve üç boyuttan (yöneticiye güven, çalışma arkadaşlarına güven ve örgüte güven) oluşmaktadır. Çalışmada kullanılan ölçeğin faktör analizine uygun olup olmadığını analiz etmek için Kaiser-Meyer-Olkin (KMO) ölçümü ve Bartlett's Küresellik Testi uygulanmıştır. Örgütsel güven ölçeğinin KMO değeri 0.949 ve Bartlett test sonucu 0.000 olarak bulunmuştur (Çizelge 1). Elde edilen bu sonuçlara göre verilerin faktör analizine uygun olduğu görülmektedir. Faktör analizi sonucunda örgütsel güven ölçeğinin 3 faktörde toplandığ 1 bulunmuştur ve 1 . faktörde 10 madde, 2 . faktörde 7 madde ve 3 . faktörde 5 madde yer almaktadır. Bu çalışma Omarov (2009) tarafından geliştirilen ölçek ile uyum göstermektedir. 1. faktörün faktör yükleri 0.598 ile 0.801 arasında, 2. faktörün yükleri 0.605 ile 0.794 arasında ve 3 . faktörün yükleri ise 0.740 ile 0.804 arasında değişmektedir. Bu üç faktör toplam varyansın yaklaşık \%75.8'ini açıklamaktadır. Örgütsel güven ölçeğinin güvenirlilik (Cronbach Alpha) değeri 0.943 çıkmıştır. Ölçeğin alt boyutlarının güvenirlilik değerleri ise şu şekildedir: Yöneticiye güven boyutunun 0.963 , çalışma arkadaşlarına güven boyutu 0.909 ve örgüte güven boyutu 0.544 'tür.

Çizelge 1. Örgütsel güven ölçeğinin faktör analizi

\begin{tabular}{|l|c|c|c|c|c|}
\hline Faktörler & $\begin{array}{c}\text { Madde } \\
\text { Say1s1 }\end{array}$ & Faktör Yükü & $\begin{array}{c}\text { Özdeğer } \\
\text { Değer }\end{array}$ & $\begin{array}{c}\text { Varyans1 } \\
\text { Aç1klama } \\
\text { Yüzdesi }\end{array}$ & $\begin{array}{c}\text { Toplam } \\
\text { Varyans } \\
\text { Yüzdesi }\end{array}$ \\
\hline Faktör 1: Yöneticiye güven & $10(1-10)$ & $0.598-0.801$ & 13.919 & 63.266 & 63.266 \\
\hline Faktör 2: Örgüte güven & $7(16-22)$ & $0.605-0.794$ & 1.561 & 7.095 & 70.362 \\
\hline $\begin{array}{l}\text { Faktör 3: Çalışma } \\
\text { arkadaşlarına güven }\end{array}$ & $5(11-15)$ & $0.740-0.804$ & 1.197 & 5.443 & 75.804 \\
\hline Kaiser-Mayer-Olkin (KMO) & \multicolumn{5}{|c|}{0.949} \\
\hline Barlett Küresellik Testi (p) & \multicolumn{5}{|c|}{0.000} \\
\hline
\end{tabular}

İşten ayrılma niyeti ölçeği olarak Wayne ve arkadaşları (1997) tarafından kullanılan ölçek kullanılmıştır (Çizelge 2). Ölçek 5 maddeden oluşmaktadır ve tek boyutludur. Yapılan faktör analizi sonucunda da ölçeğin tek faktörlü olduğu bulunmuştur. Ölçeğin faktör yükleri 0.874 ile 0.973 arasında değişmektedir. $\mathrm{Bu}$ tek faktör toplam varyansın \%89.541'ini açıklamaktadır. Ölçeğin KMO değeri 0.890 ve Barlett küresellik testi (p) anlamlı çıkmıştır ( $\mathrm{p}=0.000$ ). Ölçeğin güvenirliği 0.639 olarak bulunmuştur.

Çizelge 2. İşten ayrılma niyeti ölçeğinin faktör analizi

\begin{tabular}{|l|c|c|c|c|c|}
\hline Faktörler & $\begin{array}{c}\text { Madde } \\
\text { Sayı1 }\end{array}$ & Faktör Yükü & $\begin{array}{c}\text { Özdeğer } \\
\text { Değer }\end{array}$ & $\begin{array}{c}\text { Varyans1 } \\
\text { Açıklama } \\
\text { Yüzdesi }\end{array}$ & $\begin{array}{c}\text { Toplam } \\
\text { Varyans } \\
\text { Yüzdesi }\end{array}$ \\
\hline Faktör 1 & 5 & $0.874-0.973$ & 4.477 & 89.541 & 89.541 \\
\hline Kaiser-Mayer-Olkin (KMO) & \multicolumn{5}{|c|}{0.890} \\
\hline Barlett Küresellik Testi (p) & \multicolumn{5}{|c|}{0.000} \\
\hline
\end{tabular}

Örgütsel özdeşleşme ölçeği olarak Mael ve Ashforth (1992) tarafindan oluşturulmuş olan ölçek kullanılmıştır. Ölçek 6 maddeden oluşmaktadır. Çizelge 3 'teki KMO (0.904) ve 
Barlett test $(\mathrm{p}=0.000)$ değerleri incelendiğinde ölçeğin faktör analizine uygun olduğu da görülmektedir. Faktör analizi sonucunda ölçek tek faktörlü çıkmıştır. Bu tek faktör toplam varyansın yaklaşık \%71'ini açıklamaktadır. Faktörleri yükleri 0.774 ile 0.890 arasında değişmektedir. Ölçeğinin güvenirlilik değeri ise 0.916 olarak bulunmuştur.

Çizelge 3. Örgütsel özdeşleşme ölçeğinin faktör analizi

\begin{tabular}{|l|l|l|l|l|c|}
\hline Faktörler & $\begin{array}{l}\text { Madde } \\
\text { Sayıs }\end{array}$ & Faktör Yükü & $\begin{array}{l}\text { Özdeğer } \\
\text { Değer }\end{array}$ & $\begin{array}{l}\text { Varyans1 } \\
\text { Aç1klama } \\
\text { Yüzdesi }\end{array}$ & $\begin{array}{l}\text { Toplam } \\
\text { Varyans } \\
\text { Yüzdesi }\end{array}$ \\
\hline Faktör 1 & 6 & $0.774-0.890$ & 4.284 & 71.397 & 71.397 \\
\hline Kaiser-Mayer-Olkin (KMO) & \multicolumn{5}{|c|}{0.904} \\
\hline Barlett Küresellik Testi (p) & \multicolumn{6}{|c|}{0.000} \\
\hline
\end{tabular}

Çalışmada istatistiksel analizler için SPSS 15.0 (Statistical Package for Social Sciences) paket programı kullanılmıştır. Çalışmada tanımlayıcı istatistiksel metotlar (yüzde ve ortalama), değişkenler arasındaki ilişkinin yönü ve derecesinin belirlenmesi için pearson korelasyon analizi ve değişkenler arasındaki ilişkinin matematiksel bağıntısını tespit etmek için çoklu doğrusal regresyon analizi kullanılmıştır.

\section{Bulgular ve Tartışma}

Katılımcıların demografik özellikleri Çizelge 4'te verilmiştir. Katılımcıların \%80'ninden fazlası erkektir. Yaş grubu açısından katılımcıların \%29.8'i 34-41 yaş aralığında, \%29.5'i 42 yaş yaş ve üstü, \%26.6'sı 26-33 yaş aralığında ve \%14.1'i 18-25 yaş aralığındadır. Eğitim durumuna göre katılımcıların büyük çoğunluğu (\%81.3) lise mezunu ve aşağısı olup, ön lisans mezunu olanların oranı oldukça düşüktür (\% 7.5). İşletmedeki çalışma süresine göre incelendiğinde, katılımcıların \%75'inden fazlası 10 yıl ve aşağı süre boyunca şu anki bulunduğu işletmede çalıştı̆̆ını söylemiştir. Katılımcıların \%67.5'i mobilya sektöründe çalışırken, \%32.5'i kereste sektöründe çalışmaktadır.

Çizelge 4. Katılımcıların demografik özellikleri

\begin{tabular}{|c|l|c|c|}
\hline \multicolumn{2}{|c|}{ Demografik Özellikler } & f & $\%$ \\
\hline \multirow{4}{*}{ Cinsiyet } & Kadın & 56 & 18.4 \\
\cline { 2 - 4 } & Erkek & 249 & 81.6 \\
\hline \multirow{4}{*}{ Yaş } & $18-25$ & 43 & 14.1 \\
\cline { 2 - 4 } & $26-33$ & 81 & 26.6 \\
\cline { 2 - 4 } & $34-41$ & 91 & 29.8 \\
\cline { 2 - 4 } & 42 yaş ve üstü & 90 & 29.5 \\
\hline \multirow{5}{*}{ Eğitim } & İlkokul & 50 & 16.4 \\
\cline { 2 - 4 } & Ortaokul & 84 & 27.5 \\
\cline { 2 - 4 } & Lise & 114 & 37.4 \\
\cline { 2 - 4 } & Önlisans & 23 & 7.5 \\
\cline { 2 - 4 } & Lisans ve üzeri & 34 & 11.2 \\
\hline \multirow{5}{*}{ Çalışma Süresi } & $0-5$ y1l & 143 & 46.9 \\
\cline { 2 - 4 } & 6-10 y1l & 91 & 29.8 \\
\cline { 2 - 4 } & $11-15$ y1l & 35 & 11.5 \\
\cline { 2 - 4 } & $16-20$ y1l & 10 & 3.3 \\
\cline { 2 - 4 } & 21 y1l ve üstü & 26 & 8.5 \\
\hline \multirow{5}{*}{ Sektör } & Kereste & 99 & 32.5 \\
\cline { 2 - 4 } & Mobilya & 206 & 67.5 \\
\hline
\end{tabular}


Katılımcıların çalışma kapsamında kullanılan ölçeklere verdikleri cevapların ortalama değerleri Çizelge 5'te verilmiştir.

Çizelge 5. Katılımcıların parametrelere verdikleri cevapların ortalama değerleri

\begin{tabular}{|l|c|c|}
\hline Ölçek ve Alt Boyutlar & $\bar{X}$ & SS \\
\hline Örgütsel Güven Boyutu & 3.6703 & 0.64158 \\
\hline Yöneticiye Güven Alt Boyutu & 3.8007 & 0.83797 \\
\hline Çalışma Arkadaşlarına Güven Alt Boyutu & 3.9052 & 0.78214 \\
\hline Örgüte Güven Alt Boyutu & 3.3263 & 0.52650 \\
\hline Örgütsel Özdeşleşme Boyutu & 4.0158 & 0.90758 \\
\hline İşten Ayrılma Niyeti Ölçeği & 2.4656 & 0.70293 \\
\hline
\end{tabular}

Ölçeklere ait aritmetik ortalamaların yorumlanmasında şu sınıflandırmadan yararlanılmıştır (Özdamar, 2003); 1.00-1.79: Çok düşük, 1.80-2.59: Düşük, 2.60-3.39: Orta, 3.40-4.19: Yüksek, 4.20-5.00: Çok yüksek).

Ölçeklere ilişkin aritmetik ortalamalar incelendiğinde, örgütsel özdeşleşme (4.0158) ve örgütsel güven (3.6703) boyutlarının ortalamasının yüksek, işten ayrılma niyeti boyutunun (2.4656) ortalamasının ise düşük olduğu görülmektedir. Örgütsel güven boyutunun alt boyutları bakımından ise, katılımcılar en fazla çalışma arkadaşlarına (3.9052) güvenirken, en az ise çalıştığ işletmeye (3.3263) güvenmektedir.

Katılımcıların verdikleri cevaplara göre örgütsel güven boyutu ve alt boyutları, örgütsel özdeşleşme boyutu ve işten ayrılma boyutu arasındaki ilişki korelasyon analizi yardımıyla tespit edilmiştir ve sonuçları Çizelge 6'da gösterilmektedir. Korelasyon (r) değerlerine göre değişkenler arasındaki ilişki düzeyleri, $r$ değeri 0.89 'dan büyük ise değişkenler arasında “ çok yüksek" bir ilişki", r değeri 0.70 ile 0.89 arasında ise "yüksek" bir ilişki, r değeri 0.50-0.69 arasında ise "orta düzeyde" bir ilişki, $r$ değeri 0.26 ile 0.49 arasında ise "zayıf" bir ilişki ve $r$ değeri 0.26 'dan küçük ise "çok zayıf” bir ilişki olarak sınıflandırılmaktadır (Ersöz ve Ersöz, 2019).

Çizelge 6. Örgütsel güven, örgütsel özdeşleşme ve işten ayrılma arasındaki ilişki

\begin{tabular}{|l|c|c|c|c|c|}
\hline Değişkenler & 1 & 2 & 3 & 4 & 5 \\
\hline 1: Yöneticiye güven & 1 & & & & \\
\hline 2: Çalışma arkadaşlarına güven & $0.746^{* *}$ & 1 & & & \\
\hline 3: Örgüte güven & $0.654^{* *}$ & $0.568^{* *}$ & 1 & & \\
\hline 4: Örgütsel güven & $0.952^{* *}$ & $0.858^{* *}$ & $0.804^{* *}$ & 1 & \\
\hline 5: Örgütsel özdeşleşme & $0.417^{* *}$ & $0.476^{* *}$ & $0.447^{* *}$ & $0.490^{* *}$ & 1 \\
\hline 6: İşten ayrilma niyeti & $-0.320^{* *}$ & $-0.235^{* *}$ & $-0.239^{* *}$ & $-0.314^{* *}$ & $-0.168^{* *}$ \\
\hline ** $<0.01$
\end{tabular}

Korelasyon analizi sonuçlarına göre, örgütsel güven boyutunun alt boyutlarından olan çalışma arkadaşlarına güven ve örgüte güven boyutları ile işten ayrılma niyeti arasında negatif ve çok zayıf düzeyde bir ilişki bulunmuştur $(\mathrm{p}<0.05)$. Örgütsel güven boyutu ve yöneticiye güven alt boyutu ile işten ayrılma niyeti arasında negatif ve zayıf düzeyde bir ilişki bulunmuştur $(p<0.05)$. Örgütsel özdeşleşme boyutu ile örgütsel güven ve alt boyutları arasında ise pozitif ve zayıf düzeyde bir ilişki tespit edilmiştir $(p<0.05)$. Literatürde, örgütsel güven ile işten ayrılma niyeti arasındaki ilişkinin negatif yönlü ve anlamlı (Seçilmiş ve Kılıç, 2017; Zeffane ve Bani Melhem, 2017) ve örgütsel güven ile örgütsel özdeşleşme arasındaki ilişkinin pozitif ve anlamlı (Kalmaz, 2018; Altaş, 2021) olduğu çalışmalar bulunmaktadır. 
Korelasyon analizi sonuçlarına göre örgütsel güven alt boyutları ile örgütsel özdeşleşme ve işten ayrılma niyeti arasında anlamlı ilişkilerin olduğu tespit edildikten sonra örgütsel güven alt boyutlarının örgütsel özdeşleşme boyutuna ve işten ayrılma niyetine etkisini belirlemek için regresyon analizinden yararlanılmıştır. Kullanılan regresyon analizinde örgütsel güven alt boyutları bağımsız değişkeni gösterirken, örgütsel özdeşleşme boyutu ile işten ayrılma niyeti bağımlı değişkeni göstermektedir. Modellerde kullanılan değişkenler arasında otokorelasyon olup olmadığını belirlemek için ise Durbin-Watson testi kullanılmıştır. Çizelge 7 ve 8 incelendiğinde, Durbin-Watson değerleri 1.5 ile 2.5 arasında olduğu için bulunan modellerde otokorelasyon olmadığı anlaşılmaktadır (Kalaycı, 2016).

Çizelge 7. Örgütsel güven boyutları ile örgütsel özdeşleşme arasındaki regresyon analizi

\begin{tabular}{|l|c|c|c|c|c|}
\hline Bağımsız Değişken & $\mathrm{B}$ & Standart hata & $\beta$ & $\mathrm{t}$ değeri & Sig. \\
\hline Sabit & 1.034 & 0.297 & & 3.487 & 0.001 \\
\hline Yöneticiye güven & 0.006 & 0.088 & 0.005 & 0.065 & 0.948 \\
\hline Çalışma arkadaşlarına güven & 0.377 & 0.087 & 0.325 & 4.346 & 0.000 \\
\hline Örgüte güven & 0.447 & 0.113 & 0.260 & 3.946 & 0.000 \\
\hline $\mathrm{R}$ & \multicolumn{5}{|c|}{0.522} \\
\hline $\mathrm{R}^{2}$ & \multicolumn{5}{|c|}{0.273} \\
\hline Düzeltilmiş R ${ }^{2}$ & \multicolumn{5}{|c|}{37.671} \\
\hline $\mathrm{F}$ & \multicolumn{5}{|c|}{0.606} \\
\hline Durbin -Watson & \multicolumn{5}{|c|}{0.000} \\
\hline Anlamlılık düzeyi (p) & \multicolumn{5}{|c|}{} \\
\hline
\end{tabular}

Çizelge 7'deki regresyon analizi sonucu incelendiğinde, bağımsız değişkenlerden çalışma arkadaşlarına güven ve örgüte güven boyutları \%95 güven aralığında istatistiksel olarak anlamlı olup, bağımlı değişken olan örgütsel özdeşleşme boyutu üzerinde sırasıyla $\% 32.5$ ve \%26 oranlarında pozitif yönde bir etkide bulunmaktadır. Bağımsız değişkenlerin bağımlı değişkende meydana gelen değişimi açıklama oranı \%27.3 olarak gerçekleşmiştir.

Çizelge 8. Örgütsel güven boyutları ile işten ayrılma niyeti arasındaki regresyon analizi

\begin{tabular}{|l|c|c|c|c|c|}
\hline Bağımsız Değişken & $\mathrm{B}$ & Standart hata & $\beta$ & t değeri & Sig. \\
\hline Sabit & 3.594 & 0.255 & & 14.096 & 0.000 \\
\hline Yöneticiye güven & -0.249 & 0.076 & -0.297 & -3.294 & 0.001 \\
\hline Çalışma arkadaşlarına güven & 0.017 & 0.075 & 0.019 & 0.225 & 0.822 \\
\hline Örgüte güven & -0.074 & 0.097 & -0.055 & -0.760 & 0.448 \\
\hline $\mathrm{R}$ & \multicolumn{5}{|c|}{0.322} \\
\hline $\mathrm{R}^{2}$ & \multicolumn{5}{|c|}{0.104} \\
\hline Düzeltilmiş $\mathrm{R}^{2}$ & \multicolumn{5}{|c|}{11.634} \\
\hline F & \multicolumn{5}{|c|}{1.658} \\
\hline Durbin -Watson & \multicolumn{5}{|c|}{0.000} \\
\hline Anlaml1lık düzeyi (p) & \multicolumn{5}{|c|}{} \\
\hline
\end{tabular}

Çizelge 8 incelendiğinde ise, sadece yöneticiye güven boyutu istatistiksel açıdan anlamlı bulunmuştur. Yöneticiye güven boyutu işten ayrılma niyeti boyutu üzerinde negatif ve anlamlı bir etkisi bulunmaktadır. Yöneticiye güven boyutunun etki oranı \%29.7'dir. Yöneticiye güven, çalışma arkadaşlarına güven ve örgüte güven boyutlarının işten ayrılma niyeti boyutundaki değişimi açıklama oranı \%10.4 olarak gerçekleşmiştir. Sonuç olarak, örgütsel güvenin hem örgütsel özdeşleşme hem de işten ayrılma niyeti üzerindeki etkisinin oldukça sınırlı olduğu görülmektedir. Bu çalışma ile Hayta (2019) tarafından yapılan çalışma 
birbiriyle örtüşmektedir. Hayta (2019) yöneticiye güven alt boyutunun işten ayrılma niyeti ölçeğinin \%10'unu, kuruma güven boyutunun işten ayrılma niyeti ölçeğinin \%9'unu ve iş arkadaşlarına güven boyutunun işten ayrılma niyeti ölçeğinin \%7'sini anlamlı şekilde açıkladığını bulmuştur. Biçkes ve Yılmaz (2017) ve Çankaya (2020) yaptıkları çalışmada, yöneticiye güven ve örgüte güven boyutlarının örgütsel özdeşleşme üzerinde pozitif etkiye sahip olduğu bulunmuştur. Otel çalışanlarına yönelik yapılan başka bir çalışmada, örgütsel güvenin örgütsel özdeşleşmeyi etkilediği tespit edilmiştir (Öktem ve ark., 2016). Örgütsel güvenin işten ayrılma niyeti üzerinde negatif etkiye sahip sağlı (Sökmen, 2019), eğitim (Uzun, 2018), kamu (Sökmen, 2020), konaklama (Öktem ve ark., 2016; Öztunç, 2019) ve otomotiv (Yanık ve Naktiyok, 2017) alanlarında yapılmış çalışmalar bulunmaktadır.

\section{Sonuçlar ve Öneriler}

$\mathrm{Bu}$ çalışmada, örgütsel güven ile işten ayrılma niyeti ve örgütsel özdeşleşme arasındaki ilişki ve örgütsel güvenin işten ayrılma ve örgütsel özdeşleşme üzerine etkisi araştırılmıştır. $\mathrm{Bu}$ doğrultuda Trabzon ilinde bulunan kereste ve mobilya işletmelerinde çalışanlardan elde edilen verilere uygun olacak şekilde analizler yapılmıştır ve şu sonuçlar elde edilmiştir:

- Katılımcılar işletmelerini kendi işletmeleri gibi görmekte ve bundan dolayı çalışanlar işlerinden ayrılmayı pek düşünmemektedir. Katılımcılar en fazla mesai arkadaşlarına güvenmektedir.

- Örgütsel güven ve alt boyutları ile işten ayrılma niyeti arasında negatif bir ilişki bulunurken, örgütsel güven ve alt boyutları ile örgütsel özdeşleşme arasında pozitif bir ilişki bulunmaktadır.

- Yöneticiye duyulan güven işten ayrılma niyetini olumsuz yönde etkilerken, iş arkadaşlarına ve örgüte duyulan güven örgütsel özdeşleşmeyi pozitif yönde etkilemektedir.

- Çalışanların örgütte alınan kararları katılması sağlanarak, kendilerini örgütün bir parçası olarak görmeleri sağlanabilir. Bu şekilde çalışanlarda çalıştıkları örgütlerini kendi örgütü gibi hissedebilir. Çalışanların performansları ve güven düzeyleri yükselebilir.

- Yöneticiler, çalışanların örgüte bağlılığını yükseltecek, motivasyonlarını arttıracak organizasyonlar gerçekleştirmeli, çalışanlara işleri konusunda destek olmalı ve gerektiğinde koçluğu yerinde ve zamanında çalışanına sağlamalıdır.

- Örgütte bir kişinin işten ayrılması maddi ve manevi açıdan örgütü olumsuz etkileyeceğinden dolayı örgütler işten ayrılma niyetinde olan çalışanları tespit etmeye çalışabilir ve çalışanları işten ayrılmaya iten etmenleri araştırarak gerekli önlemleri alabilir.

- Çalışmada çalışanların örgütsel özdeşleşme düzeyleri iyi düzeyde bulunmuş olsa da yöneticiler çalışanların örgütsel özdeşleşme düzeylerini arttırması için etkin ve adil bir ödüllendirme sistemi kurabilir, çalışanların ücretlerinde ve sosyal haklarında çalışanları memnun edici iyileştirmeler yapabilir, çalışanların çalışma koşulları daha uygun hale getirilebilir.

\section{Yazar Katkıları}

Nadir Ersen: Çalışmanın tasarlanması, anket çalışmalarının yapılması, verilerin analiz edilmesi, analiz sonuçlarının yorumlanması, makalenin yazılması, Öner Karayiğit: Anket çalışmalarının yapılması, verilerin analiz edilmesi, Bahadır Çağrı Bayram: Analiz sonuçlarının yorumlanması, makalenin yazılması, İlker Akyüz: Makalenin düzenlenmesi 


\section{Kaynaklar}

Altaş, S. S., (2012), Sağlık çalışanlarının örgütsel özdeşleşme, örgütsel bağlılık, örgütsel güven ve örgütsel destek algıları arasındaki ilişkiler, Işsletme Araştırmaları Dergisi, 13(1), 875-891.

Biçkes, D. M., Yılmaz, C. (2017), Çalışanların örgütsel güven algılamalarının özdeşleşme düzeyleri üzerindeki etkisi: amprik bir çalışma, Kahramanmaraş Sütçü İmam Üniversitesi Sosyal Bilimler Dergisi, 14(1), 301-322.

Blader, S. L., Patil, S., Packer, D. J., (2017), Organizational identification and workplace behavior: more than meets the eye, Research in Organizational Behavior, 37, 19-34.

Cotton, J. L., Tuttle, J. M., (1986), Employee turnover: a meta-analysis and review with implications for research, Academy of Management Review, 11(1), 55- 70.

Çankaya, M., (2020), Örgütsel güvenin örgütsel özdeşleşme üzerindeki etkisi: sağlık sektöründe bir uygulama, Akademik Sosyal Araştırmalar Dergisi, 8(107), 185-204.

Dorman, J. S., La Porte, R. E., Stone, R. A., Trucco, M., (1990), Worldwide differences in the incidence of type I diabetes are associated with amino acid variation at position 57 of the HLA-DQ beta chain, Proc Natl Acad Sci U S A, 87(19), 7370-7374.

Ersöz, F., Ersöz, T., (2019), İstatistik-I, Seçkin Yayıncılık, Ankara, 2019.

Gemlik, N., (2018), Hastahane yöneticiliği temel yaklaşımlar ve öneriler, Nobel Akademik Yayınc1lık, Ankara, 2018.

Guzzo, R. F., Wang, X., Madera, J. M., Abbott, J., (2021), Organizational trust in times of COVID-19: hospitality employees' affective responses to managers' communication, International Journal of Hospitality Management, 93, 1-11.

Halis, M., Gökgöz, G. S., Yaşar, Ö., (2007), Örgütsel Güvenin Belirleyici Faktörleri ve Bankacılık Sektöründe Bir Uygulama, Sosyal Bilimler Dergisi, 17, 187-205.

Hamzagic, E., (2018), The Importance of the organizational identification in forming organizational perception, International Review, 1-2, 1-11.

Hayta, Ö., (2019), Hemşirelerin örgütsel güven düzeylerinin işten ayrılma niyeti üzerine etkisi, Marmara Üniversitesi, Sağllk Bilimleri Enstitüsü, İstanbul, Yüksek Lisans Tezi.

Hinkin, T. R., Tracey, J. B., (2000), The cost of turnover: putting a price on the learning curve, Cornell Hotel and Restaurant Administration Quarterly, 41, 14-21.

Ismaeel, P. B., (2020), The effect of mobbing at workplace on employees intention to leave the job and the law of mobbing (a case study in governmental institutions in Erbil/Iraq), Istanbul Okan University, Institute of Social Sciences, İstanbul, Master Thesis.

İşçan, Ö.F., (2006), Dönüştürücü/etkileşimci liderlik algısı ve örgütsel özdeşleşme ilişkisinde bireysel farkl11ıkların rolü, Akdeniz I.I.B.F. Dergisi, 11, 160-177.

Kalaycı, Ş., (2016), SPSS uygulamalı çok değişkenli istatistik teknikleri, Asil Yayın Dağıtım, Ankara, 2016.

Kalmaz, P. E., (2018), Örgütsel güvenin örgütsel özdeşleşme ve mesleki özdeşleşme üzerine etkileri hakkında bir araştırma, Pamukkale Üniversitesi, Sosyal Bilimler Enstitüsü, Denizli, Doktora Tezi. 
Karaman, H., (2015), Açımlayıcı faktör analizinde kullanılan faktör çıkartma yöntemlerinin karşılaştırılması, Hacettepe Üniversitesi, Ĕ̈itim Bilimleri Enstitüsü, Ankara, Yüksek Lisans Tezi.

Karanika-Murray, M., Duncan, N., Pontes, H. M., Griffiths, M. D., (2015), Organizational identification, work engagement and job satisfaction, Journal of Managerial Psychology, 30(8), 1019-1033.

Mael, F., Ashforth, B., (1992), Alumni and their alma mater: a partial test of the reformulated model of organizational identification, Journal of Organizational Behavior, 13(2), 103123.

Omarov, A., (2009), Örgütsel güven ve iş doyumu: özel bir sektörde uygulama, Dokuz Eylül Üniversitesi, Sosyal Bilimler Enstitüsü, İmir, Yüksek Lisans Tezi.

Öktem, Ş., Kızıltan, B., Tarhan, M., (2016), Örgütsel güven ile örgüt ikliminin örgütsel özdeşleşme, iş tatmini ve işten ayrılma niyeti üzerine etkileri: otel işletmelerinde bir uygulama, Işsletme Araştırmaları Dergisi, 8(4), 162-186.

Özdamar, K., (2003), Modern bilimsel araştırma yöntemleri, Kaan Kitabevi, Eskişehir, 2003.

Öztunç, E., (2019), Liderlik tarzlarının işten ayrılma niyeti üzerine etkisi ve örgütsel güvenin aracı rolü: konaklama işletmeleri üzerine bir araştırma, İstanbul Gelişim Üniversitesi, Sosyal Bilimler Enstitüsü, İstanbul, Yüksek Lisans Tezi.

Riketta, M., (2005), Organizational identification: a meta-analysis, Journal of Vocational Behavior, 66(2), 358-384.

Rousseau, D. M., Sitkin, S. B., Burt, R. S., Camerer, C., (1998), Not so different after all: A cross-discipline view of trust, Academy of Management Review, 23(3), 393-404.

Sanderson, P., (2003), The relationship between empowerment and turnover intentions in a structured environment: an assessment of the navy's medical service corps, Regent University, Virginia, Doctoral Dissertation.

Scott, S. G., Lane, V. R., (2000), A stakeholder approach to organizational identity, The Academy of Management Review, 25(1), 43-62. DOI: https://doi.org/10.2307/259262.

Sökmen, A., (2019), Etik liderlik, örgütsel güven, iş tatmini ve işten ayrılma niyeti ilişkisi: bir hastane işletmesinde araştırma, Üçüncü Sektör Sosyal Ekonomi Dergisi, 54(2), 917-934.

Sökmen, A., (2020), Örgütsel adaletin iş tatmini ve işten ayrılma niyetine etkisinde örgütsel güvenin aracı rolü: kamu sektöründe bir araştırma, Üçüncü Sektör Sosyal Ekonomi Dergisi, 55(4), 2651-2663.

Seçilmiş, C., Kılıç, İ., (2017), Örgütsel güven, iş-aile yaşam çatışması ve işten ayrılma niyeti ilişkisinin belirlenmesi: seyahat acentelerinde bir uygulama, Turizm Akademik Dergisi, 4(1), 65-79.

Taştan, E. M., (2020), Örgütsel özdeşleşme ve örgüte bağl1lık ilişkisi: İBB örneği, İbn Haldun Üniversitesi, Lisansüstü Ĕ̈itim Enstitüsü, İstanbul, Yüksek Lisans Tezi.

URL1, (2021), https://sanayi.tobb.org.tr/, son erişim tarihi; 20.09.2021.

Uzun, T., (2018), Öğretmenlerin algıladığı örgütsel destek ile örgütsel özdeşleşme ve işten ayrılma niyeti arasındaki ilişki: örgütsel güvenin aracı rolü, Karadeniz Sosyal Bilimler Dergisi, 10(18), 133-155. 
Wayne, S. J., Shore, L. M., Liden, R. C., (1997), Perceived organizational support and leadermember exchange: a social exchange perspective, Academy of Management Journal, 40(1), 82-111.

Yanık, O., Naktiyok, A., (2017), Etik (ahlaki) liderliğin çalışanların iş tatminine, örgütsel bağlılığına ve işten ayrılma niyetine etkisinde örgütsel güven ve örgütsel adalet algısının arac1 rolü, Bartın Üniversitesi İ.I.B.F. Dergisi, 8(15), 297-323.

Yenihan, B., Öner, M., Çifyıldız, K., (2014), İş stresi ve işten ayrılma niyeti arasındaki ilişski: otomotiv işletmesinde bir araştırma, Çalışma İlişkileri Dergisi, 5(1), 38-49.

Yücel, İ., Demirel, Y., (2013), Mevcut iş alternatiflerinin iş tatmini ve işten ayrılma ilişkisi üzerinde etkisi: "başka bir yol daha olmalı!", Atatürk Üniversitesi İktisadi ve İdari Bilimler Dergisi, 27 (2)., 159-177.

Zeffane, R. Bani Melhem, S. J., (2017), Trust, job satisfaction, perceived organizational performance and turnover intention: A public-private sector comparison in the United Arab Emirates, Employee Relations, 39(7), 1148-1167. 